\title{
Erratum to: TVT versus TOT, 2-year prospective randomized study
}

\author{
Bassem S. Wadie · Ahmed S. El-Hefnawy
}

Published online: 14 December 2012

(C) Springer-Verlag Berlin Heidelberg 2012

\section{Erratum to: World J Urol}

DOI 10.1007/s00345-012-0956-4

Unfortunately, the coauthor Elhefnawy's name was incorrectly spelled in the author group of the original publication. The correct author group is given below:

Bassem S. Wadie · Ahmed S. El-Hefnawy

The online version of the original article can be found under doi:10.1007/s00345-012-0956-4.

B. S. Wadie · A. S. El-Hefnawy

Voiding Dysfunction and Incontinence Unit,

Urology and Nephrology Center,

Mansoura University, Mansoura, Egypt

B. S. Wadie ( $\square)$

Voiding Dysfunction and Female Urology Unit,

Urology and Nephrology Center,

Mansoura University, Mansoura, Egypt

e-mail: bassem_wadie@mans.edu.eg 